\title{
Development of Bench Scale Water Treatment Unit for the Treatment of Medium Turbid Water: The Use of Natural Coagulant
}

\author{
Jezhi Paul Yero ${ }^{1}$, Idris Misau Muhammad ${ }^{2}$, Adamu Mohammad Bello ${ }^{2}$, \\ Abdulwadud Abdulkarim Yusuf ${ }^{2}$, Atiku Yakubu Musa ${ }^{2}$
}

${ }^{1}$ Kaduna Refining and Petrochemical Company

KM 16 Kachia Road, P. M. B 2252, Kaduna, Nigeria

${ }^{2}$ Abubakar Tafawa Balewa University

Tafawa Balewa Way, P. M. B. 0248, Bauchi, 740272, Nigeria

DOI: $10.22178 /$ pos.66-4

LCC Subject Category: SB1-1110

Received 22.11.2020

Accepted 26.01.2021

Published online 31.01.2021

Corresponding Author:

Abdulwadud Abdulkarim Yusuf

aabdulwadud@atbu.edu.ng

(C) 2020 The Authors. This article is licensed under a Creative Commons Attribution 4.0

License @ (1)

\begin{abstract}
Water purification is a process used to enhance water quality and make it more acceptable for specific end-use. The rising increase for portable drinking water has made natural coagulant application for water purification a welcome development. Most reported researches were on the use of natural coagulants in a laboratory batch scale. Because of those above, a bench-scale laboratory study was carried out on the application of Balanites Aegyptiaca seed as a natural coagulant. The outcome showed its usefulness toward water purification. This paper reported the developed bench-scale water treatment plant's performance utilising Balanites Aegyptiaca seed stock solution and the powdered kennel as biocoagulant. Some design equations were adopted. The treatment units considered include coagulation/flocculation, sedimentation, and filtration. The total tank design capacity was 20 litres with the overflow area's actual size for sedimentation of 7.46 litres. $0.5 \mathrm{Hp}$ electric motor with a speed of $600 \mathrm{rpm}$ and a speed gear drop of $120 \mathrm{rpm}$ were selected. $0.0127 \mathrm{~m}$ pipe flow line diameter connecting the tanks with a corresponding pipe flow velocity of $0.108 \mathrm{~m} / \mathrm{s}$ was obtained from the design. However, in both the coagulation, sedimentation and filtration units, the material balance obtained showed a steadiness in the material flow across sedimentation and filtration units. However, among the parameters tested in the raw turbid water, the turbid water revealed turbidity of 514 NTU, the colour of $5600 \mathrm{CTU}$, the conductivity of $276 \mu \mathrm{s} / \mathrm{cm}, \mathrm{pH}$ of 7.10 and total coliform bacteria count of $85 \mathrm{CFU} / 100 \mathrm{~mL}$ which were above the recommended set standard of WHO and NIS. The result of the treated water using the stock solution and the powdered kennel (bio-coagulant) on the developed water treatment unit showed a remarkable reduction in the tested parameters in the raw turbid water used for the treatment process. Total coliform count reduces from $85 \mathrm{CFU} / 100 \mathrm{ml}$ to $10 \mathrm{CFU} / \mathrm{ml}$ in both cases. It was observed that conductivity increases after the treatment, but other inorganic constituents reduce significantly though not to WHO and NIS's recommended set standard. The 0-dosage treatment conducted also showed a reduction in all the tested parameters.
\end{abstract}

Keywords: pollutant; microbes; bench-scale; water purification; turbidity; biocoagulant.

\section{INTRODUCTION}

Currently, the water crisis is a severe issue of global concern; it has been reported by [12] that in the developing countries more than 1.6 million people are using unhygienic water and among them, most of the people suffer from diarrhoea and water-related diseases. Such reasons also necessitate a sustainable, cost-friendly alternative treatment process to overcome the current water challenges. Surface water/well water can contain suspended solids, colloidal matter, organics, silica, iron, manganese and many other pollutants. That is why it is so necessary to treat it before consumption. Carrying out studies using developed bench-scale water treatment plant have the advantage of requiring a small volume of sample testing, allowing a fast screening of various 
alternative and testing of many performance variables at a relatively minimum cost. Other studies reported aluminium, which is the significant alum component and poly aluminium chloride, causes Alzheimer's disease [20]. Authors [3] also noted that the natural organic matter combines with Chlorine during water treatment when applied for disinfection hence, generate disinfection byproducts (DBPs) and in particular forms halogenated DBPs, this enhances the production of free radicals in the body.

The removal of turbidity and pathogens is an essential step in the water treatment process, and generally, this is achieved using coagulation and chlorination processes. In conventional water treatment processes, aluminium sulphate (alum) and poly aluminium chloride (PAC) is widely used for turbidity removal, while Chlorine is used to disinfect pathogens.

Balanites aegyptiaca is a tree species, classified either as a member of the Zygophyllaceae or the Balanitaceae. This tree is native to much of Africa and parts of the Middle East. There are many common names for this plant. In English, the fruit has been called desert date, soapberry tree or bush, Thorn tree, Egyptian myrobalan, Egyptian balsam or Zachum oil tree; in Arabic, it is known as lalob, hidjihi, inteishit, and healing (hijlij). In Hausa, it is called aduwa, in Swahili mchunju [21]. Authors [4] reported that desert date' has a long history of traditional uses for wide disease ranges. It has been experimentally proved that Balanites aegyptiaca Del possess antioxidant, antimicrobial, anticancer, diuretic, hypocholesterolemia, wound healing, antiviral, antidiabetic, hepatoprotective, mosquito larvicidal, anti-inflammatory and analgesic, antivenin, anthelmintic, cardioprotective cum antioxidant activity, and antinociceptive properties [4].

Bark, fruits, seeds, seed oil, and leaves of this plant are widely used in folk medicine, all parts of the desert date tree plant have medicinal uses including fruits, seeds, barks and roots [8], and it was also observed and reported by [14] that Balanites aegyptiaca seed could be a potential natural coagulant in raw wastewater treatment. On the other hand, authors [10] said that PAC and alum continuous usage in large amounts are a potential threat for processed water consumers' health because coagulant may remain, although in a small amount. Ecologically, synthetic coagulant use produces a certain amount of sludge sediment that is a pollutant for the environment. The sludge is relatively tricky to degrade and can change soil and water minerals' composition from the normal condition. Thus, in recent years there has been considerable interest in the development of natural coagulants. Some studies on natural coagulants have been carried out. Various natural coagulants were produced or extracted from plants such as Moringa oleifera (M0), Prosopis juliflora, Tamarindus indica and Cactus latifaria [20]. Natural organic polymers have been used for more than 2000 years in India, Africa, and China as effective coagulants and coagulant aids in turbidity treatment. Natural coagulants have bright future and are concerned by several researchers due to their abundant source, low price, environment friendliness, multifunction, unlikely to produce treated water with extreme $\mathrm{pH}$ and biodegradable nature in water purification, highly biodegradable. Also, naturally occurring coagulants are usually presumed safe for human health [16].

\section{MATERIALS AND METHODS}

The materials used for this study include among other raw turbid water, Balanites aegyptiaca seed, sterile containers, petri dishes, distilled water and plastic containers. The equipment used in this study includes turbidity meter, $\mathrm{pH}$ meter, electronic balance, drying oven, blender, soxhlet extractor, jar test machine, centrifuge, photometer and desiccator.

Botanical Name and Description of Balanites aegyptiaca (Desert Date). Balanites aegyptiaca is a multi-branched, spiny shrub or tree up to $10 \mathrm{~m}$ tall. Crown spherical, in one or several distinct masses. Trunk short and often branching from near the base. Bark dark brown to grey, deeply fissured. Branches armed with stout yellow or green thorns up to $8 \mathrm{~cm}$ long. Leaves with two separate leaflets; asymmetric, 2.5 to $6 \mathrm{~cm}$ long, bright green, leathery, with fine hairs when young. Flowers in fascicles in the leaf axils are fragrant, yellowish-green [9]. Plate 1 presents the image of the desert date.

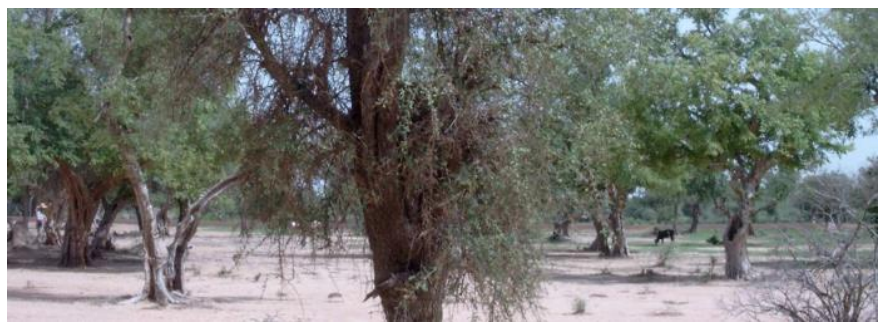

Figure 1 - Image of Desert Date [2] 
Design of Tanks. For this work's purpose, some storage vessels/ containers were designed and fabricated; the plates manufactured are assumed to be cylindrical. The formula for the volume of the cylinder is shown in Equation 1.

$$
V_{c}=\pi r^{2} h_{c}
$$

where $\mathrm{VC}=$ volume of the cylinder; $r=$ radius of the cylinder; $h_{c}=$ height of the cylinder.

The design flow rate was calculated according to Equation 2.

$$
\text { Design flow rate }=\frac{\text { Tank capacity }(\text { Litre })}{\text { Retension time }(\text { minute })}(2)
$$

The impeller diameter was calculated by applying the rule of thumb, as shown in Equation 3.

$$
\frac{D_{i}}{D T}=0.33
$$

where $\mathrm{D}_{\mathrm{i}}=$ impeller diameter; $\mathrm{DT}=$ tank diameter.

The impeller distance from the base of the tank was calculated according to Equation 4.

$$
\frac{H_{b}}{D_{i}}=1 \text { (for flat blade turbine) }
$$

$\mathrm{H}_{\mathrm{b}}=\mathrm{D}_{\mathrm{i}}=8 \mathrm{~cm}$

The impeller width (wi) was calculated according to Equation 5.

$$
\frac{W_{i}}{D_{i}}=0.2
$$

$\mathrm{W}_{\mathrm{i}}=0.2 \times \mathrm{D}_{\mathrm{i}}$

Table 1 results from Parameters Considered's calculated values in the Design of Coagulation / Flocculation Unit. For this design work, sedimentation occurred at the space of overflow.

Table 1 - Parameters Considered for the Design of Coagulation/ Flocculation Units

\begin{tabular}{|l|l|l|}
\hline \multicolumn{1}{|c|}{ Parameter } & \multicolumn{1}{c|}{ Value } & \multicolumn{1}{c|}{ Unit } \\
\hline Design flow rate & 0.82 & $\mathrm{~L} / \mathrm{min}$ \\
\hline $\begin{array}{l}\text { The total diameter of coagulation } \\
\text { tank }\end{array}$ & 22.00 & $\mathrm{Cm}$ \\
\hline Impeller diameter & 8.00 & $\mathrm{Cm}$ \\
\hline Impeller width & 2.00 & $\mathrm{Cm}$ \\
\hline
\end{tabular}

\begin{tabular}{|l|l|l|}
\hline \multicolumn{1}{|c|}{ Parameter } & Value & \multicolumn{1}{c|}{ Unit } \\
\hline $\begin{array}{l}\text { The total diameter of the } \\
\text { coagulation and sedimentation } \\
\text { tank }\end{array}$ & 30.00 & $\mathrm{Cm}$ \\
\hline $\begin{array}{l}\text { Height of the sedimentation tank } \\
\text { (Hs) }\end{array}$ & 28.00 & $\mathrm{Cm}$ \\
\hline $\begin{array}{l}\text { Height of the coagulation tank } \\
\text { (Hc) }\end{array}$ & 32.00 & $\mathrm{Cm}$ \\
\hline $\begin{array}{l}\text { Total volume of coagulation+ } \\
\text { sedimentation tank }\end{array}$ & 20.00 & $\mathrm{Litre}$ \\
\hline $\begin{array}{l}\text { The actual size of overflow } \\
\text { (Sedimentation) }\end{array}$ & 7.46 & Litre \\
\hline The capacity of electric motor & 0.50 & $\mathrm{Hp}$ \\
\hline Speed of the electric motor & 600.00 & $\mathrm{Rpm}$ \\
\hline Speed gear drop & 120.00 & $\mathrm{Rpm}$ \\
\hline
\end{tabular}

Figure 2 is the schematic diagram of the benchscale water treatment plant. Figure 3 is the design layout of the coagulation and sedimentation tank with its dimensions in centimetre.

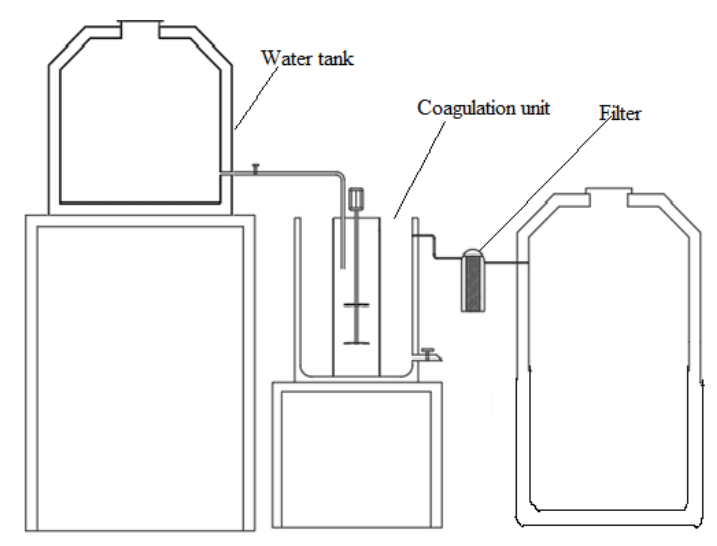

Figure 2 - Schematic diagram of the bench-scale water treatment plant

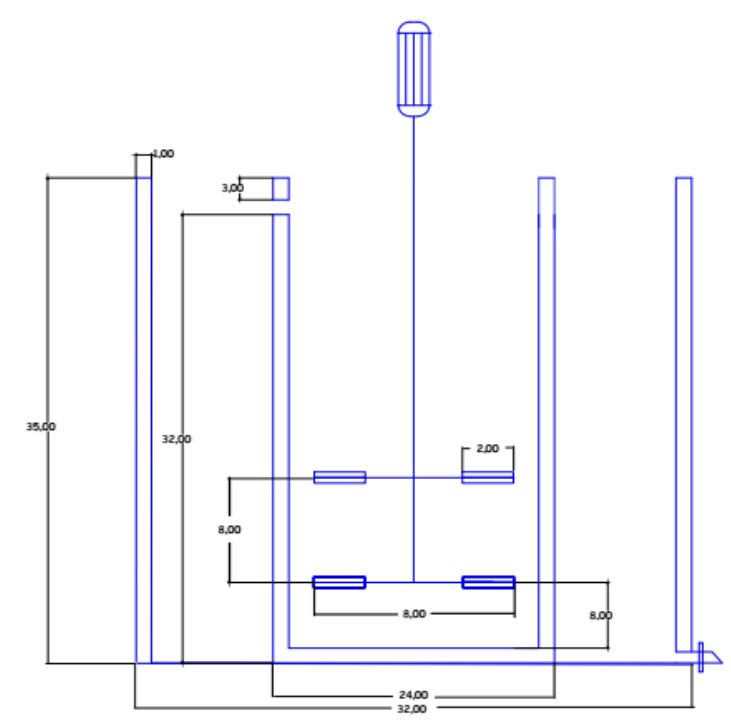

Figure 3 - Design layout of coagulation and sedimentation tank (1) 


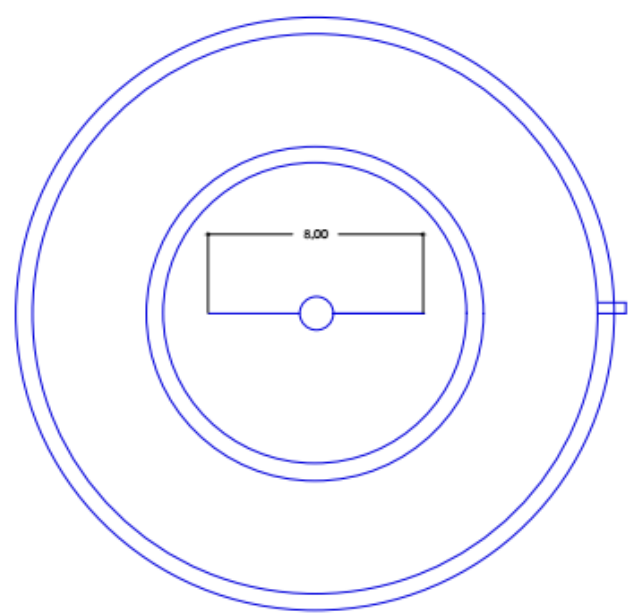

Figure 3 - Design layout of coagulation and sedimentation tank (2)

Design of Piping, Valves and Treatment Unit Supporting Stand. Materials were used to fabricate the bench-scale water treatment unit, such as pipes and valves. A $0.0127 \mathrm{~m}$ flow line diameter connecting the unit was considered with a corresponding flow velocity of $0.108 \mathrm{~m} / \mathrm{s}$. Details on some of these materials are presented in Table 2.

Table 2 - Materials, Sizes and Their Description

\begin{tabular}{|l|l|l|}
\hline Materials used & $\begin{array}{c}\text { Size } \\
\text { (inch) }\end{array}$ & \multicolumn{1}{|c|}{ Description } \\
\hline $\begin{array}{l}\text { Galvanised } \\
\text { steel pipe }\end{array}$ & $3 / 4$ & $\begin{array}{l}\text { Pipe used in } \\
\text { constructing the } \\
\text { supporting unit } \\
\text { stand. }\end{array}$ \\
\hline Gate valve & $1 / 2$ & $\begin{array}{l}\text { Full flow coated } \\
\text { aluminium handle } \\
\text { and threaded ends. }\end{array}$ \\
\hline $\begin{array}{l}\text { PVC gate } \\
\text { valves }\end{array}$ & $1 / 2$ & $\begin{array}{l}\text { Two-ends threaded } \\
\text { PVC gate valve }\end{array}$ \\
\hline $\begin{array}{l}\text { Socket gate } \\
\text { valve }\end{array}$ & $1 / 2$ & $\begin{array}{l}\text { Threaded PVC } \\
\text { socket gate valve }\end{array}$ \\
\hline $\begin{array}{l}\text { Double union } \\
\text { gate valve }\end{array}$ & $1 / 2$ & $\begin{array}{l}\text { Low-pressure } \\
\text { double union } \\
\text { threaded gate valve }\end{array}$ \\
\hline $\begin{array}{l}\text { Discharge } \\
\text { treated water } \\
\text { valve }\end{array}$ & $1 / 2$ & $\begin{array}{l}\text { Valve for the outflow } \\
\text { of treated water. }\end{array}$ \\
\hline
\end{tabular}

Development of Bench Scale Water Treatment Unit. Before the fabrication's commencement, the emphasis was given to selecting the vision materials, including pipe fittings, valves unions and gates valve, types of metals, electric motor capacity, and mixing blade type for suitability. The coagulation unit was designed to be $12.33 \mathrm{l}$ capacity with a flow rate of $0.82 \mathrm{~L} / \mathrm{min}$; the coagulation/flocculation unit was also designed with a total volume of $20.00 \mathrm{l}$ having a full size of overflow area of 7.46 $\mathrm{l}$. The impeller used has a width of $2.00 \mathrm{~cm}$. Its diameter from the tank's base is $8.00 \mathrm{~cm}$, fabrication work was carried out using stainless steel for the primary treatment unit and cylindrical plastic containers for the storage tanks. Galvanised steel was used for the construction of the companies supporting stand. The gravitational force was considered during the design to overcome the challenges of pumping. Also, corrosion challenges were considered in selecting the materials during the fabrication stage.

Sample Collection / Preparation. Balanites aegyptiaca seed, also known as desert date obtained from the local market was weighed and soaked in water for 5 hours, washed thoroughly to remove the pulp, sundried, weighed again. The shell was cracked to obtain the seed kernel using a metal hammer. The seed kernel was weighed and then ground to increase the surface area using mortar and pestle. The ground sample was dried in an oven at $80^{\circ} \mathrm{C}$ till constant weight then sieved. One hundred and fifty grams (150 g) ground kernel was charged into a Soxhlet extractor to extract the dried sample oil. The residue/cake from the extraction process was washed severally with distilled water, and then oven-dried. The soaked/dried residue was weighed and then kept in an airtight container for bio-coagulant use.

Method of Seed Oil Extraction. One hundred and fifty grams (150 g) of the prepared sample of Balanites aegyptiaca seed was taken inside a thimble made from thick filter paper, which was loaded into the main chamber of the Soxhlet extractor. The Soxhlet extractor was placed on to a flask containing the extraction solvent. The Soxhlet was then equipped with a condenser, and $250 \mathrm{ml}$ of the solvent was heated to reflux. The solvent vapour travelled up a distillation arm and flooded into the chamber housing the thimble of solid. The chamber containing the solid material was slowly filled with warm solvent. When the Soxhlet chamber was almost full, the chamber was automatically emptied by a siphon sidearm, with the solvent running back down to the distillation flask. After many cycles, the desired compound was concentrated in the distillation flask. In this study normal-hexane ( $\mathrm{N}$-hexane) was used as a solvent. The micellar, a mixture of oil and solvent, from the distillation flask, which was concentrated, was then taken off for distillation to evaporate the 
solvent used and retain the oil [11]. Besides, the Soxhlet extraction process was carried out eight times until a total of one thousand two hundred grams (1200 g) of the ground sieved seed kernel was successfully extracted.

Microbiological Properties of the Sample. The following steps were followed to determine coliform bacteria's presence [6]. Membrane lauryl sulphate broth was dissolved in $100 \mathrm{ml}$ of distilled water. Membrane filter was inserted into filter vacuum, one hundred millilitres $(100 \mathrm{ml})$ of the sample was measured and put into the vacuum filter and filtered. Adsorption path was put into Petri dish, and membrane lauryl solution was added, the membrane was removed and inserted into the Petri dish and covered. Petri dish was put into the oven and incubated at $35{ }^{\circ} \mathrm{C}$ for $18 \mathrm{~h}$. Hand lens was used in counting the coliform bacteria present.

Description of Experimental Setup and Water Treatment. The raw water was characterised for water quality parameters, and the Balanites aegyptiaca seed was processed, during the processing, oil extraction was performed, and dried powdered of the processed Balanites aegyptiaca seed was then used as a coagulant, based on the jar test result in the seed powder was then applied for the coagulation and flocculation experiment. Also, $10 \mathrm{~g}$ was dissolved in $100 \mathrm{ml}$ of distilled water and then filtered to prepare the coagulant's saturated solution, and the extract was then used for the water purification. The treated water was then allowed to sediment and finally passed through the filter for removal of solutes. The treated water was then re-tested as earlier done on the sample before treatment for water quality parameters and the result compared with the standard. The whole water treatment process was performed within the design and developed water treatment units.

\section{RESULTS AND DISCUSSIONS}

Extraction of Oil from Balanites aegyptiaca Seed Powder and Sample Characterization. Balanites aegyptiaca seed used in this study could be a creamy oil source for domestic and industrial applications if correctly processed. It was also observed from the result in Table 3, which contained values for the factors used for the extraction of oil from Balanites aegyptiaca seed kernel. The results showed that temperature, extraction time, and particle size were among the factors that affected the extract's yields during oil extraction from the seeds. This is because the increase in temperature, particle size, and extraction time significantly influence the result during the extraction process. It was also observed that the percentage yield of the oil (extract) during the extraction process was $38.42 \%$. The oil density was found to be $0.84 \mathrm{~g} / \mathrm{cm} 3$, and this result obtained complies with the literature as written by $[18,22]$. The finding further revealed that the more the surface area, the lower the extraction time and the more the yield of the extract, this finding complies with the literature as reported by [14], seed sample for the oil extraction process was sieved through $0.6 \mathrm{~mm}$ sieve size before experimentation. Detail of the result obtained is as shown in Table 3.

Table 3 - Factors Used and the Responses Obtained for the Oil Extraction

\begin{tabular}{|c|c|c|c|c|}
\hline $\begin{array}{c}\text { Particle } \\
\text { size } \\
(\mathrm{mm})\end{array}$ & $\begin{array}{c}\text { Tempera- } \\
\text { ture }{ }^{\circ} \mathrm{C}\end{array}$ & $\begin{array}{c}\text { Extraction } \\
\text { Time }(\mathrm{hr})\end{array}$ & $\begin{array}{c}\text { Oil } \\
\text { yield } \\
(\%)\end{array}$ & $\begin{array}{c}\text { Oil } \\
\text { Density } \\
\mathrm{g} / \mathrm{cm}^{3}\end{array}$ \\
\hline 0.60 & 50.00 & 4.00 & 38.42 & 0.83 \\
\hline
\end{tabular}

However, the sample characterisation result was adopted from the previous research conducted [14], X-ray fluorescence (XRF) analysis revealed that the sample contains $\mathrm{Fe}_{2} \mathrm{O} 3, \mathrm{SiO}_{2}, \mathrm{CaO}$, which stabilises the $\mathrm{pH}$. At the same time, $\mathrm{Ag}_{2} \mathrm{O}$, and $\mathrm{ZnO}$ gives the disinfection properties, scanning electron microscope (SEM) shows back detector Images of the crushed Balanites aegyptiaca seed hence, the finely ground powder of the root is in particle structure, Brunauer Emmett and Teller (BET) result revealed total pore volume of $0.003008 \mathrm{~cm}^{3} / \mathrm{g}$.

BET surface area of $11.224953 \mathrm{~m}^{2} / \mathrm{g}$ and adequate surface area increases the chemical reaction, FTIR result showed functional groups such as $\mathrm{OH}\left(1^{\circ}\right.$ alcohol), amine ( $\left.-\mathrm{NH}_{2}\right), \mathrm{C}=\mathrm{O}$ (Carboxyl) and $-\mathrm{C}=\mathrm{C}$ - symmetric stretching of alkenes by adsorption at different frequency band among others and at the functional group site the reaction takes place [14]. The proximate analysis results revealed moisture content of $3.65 \%$, oil yield of $41.00 \%$, protein content of $36.60 \%$, ash content of $3.76 \%$, nitrogen content of $5.58 \%$ and carbon content of $9.70 \%$ [14].

Physico-Chemical and Microbiological Properties of Turbid Water before and after treatment Using the Fabricated Water Treatment Units. The outcome of the physicochemical and microbiological 
characteristic of the turbid water before treatment revealed that all the tested parameters were above the recommended value set by [15] for safe quality drinking water except $\mathrm{pH}$ and conductivity which were within the acceptable range hence, the need for the treatment and this finding is in line with the literature as reported by [13].

Authors [10] also, this same finding complies with the set standard by [15]. It was also observed that the turbidity had exceeded the range of 50 150 NTU classified as medium turbid water as reported by $[7,13]$, detailing the findings obtained as presented in table 7. Furthermore, Table 4, 5 and 6 show the results of material balances for the coagulation tank, sedimentation tank and the filtration unit. It was observed from the material balances that steady-state operation was considered during the treatment process.

Table 4 - Material Balance for the Coagulation Tank

\begin{tabular}{|l|c|c|c|}
\hline \multicolumn{1}{|c|}{ Component $(\mathrm{g})$} & $\operatorname{In}(\mathrm{S} 1)$ & $\operatorname{In}(\mathrm{S} 2)$ & Out(S3) \\
\hline Water & 12100 & 100 & 12200 \\
\hline Nitrate $\left(\mathrm{NO}_{3}\right)$ & 0.2302263 & 0 & 0.18804368 \\
\hline Iron $(\mathrm{Fe})$ & 0.10406 & 0 & 0.10043 \\
\hline Fluoride $(\mathrm{F}-)$ & 0.0000 & 0 & 0.001573 \\
\hline Chloride $(\mathrm{Cl})$ & 0.06655 & 0 & 0.05445 \\
\hline Sulphate $\left(\mathrm{SO}_{4}\right)$ & 0.8833 & 0 & 0.8833 \\
\hline Phosphate $\left(\mathrm{PO}_{4}\right)$ & 0.0242 & 0 & 0.020449 \\
\hline Potassium $(\mathrm{K})$ & 0.3872 & 0 & 0.10891111 \\
\hline Copper $\left(\mathrm{Cu}^{2+}\right)$ & 0.121 & 0 & 0.115918 \\
\hline Bio-coagulant & 0.000 & 10 & 10.343509 \\
\hline & 12101.82 & 110 & 12211.8166 \\
\hline
\end{tabular}

Table 5 - Material Balance for the Sedimentation Tank

\begin{tabular}{|l|c|c|c|}
\hline \multicolumn{1}{|c|}{ Component $(\mathrm{g})$} & $\mathrm{In}(\mathrm{S} 3)$ & Sludge(S4) & Out(S5) \\
\hline Water & 12200 & 1220 & 10980.0000 \\
\hline Nitrate $\left(\mathrm{NO}_{3}\right)$ & 0.1880 & 0.018804368 & 0.1693 \\
\hline Iron $(\mathrm{Fe})$ & 0.1004 & 0.010043 & 0.0904 \\
\hline Fluoride $(\mathrm{F}-)$ & 0.0016 & 0.0001573 & 0.0014 \\
\hline Chloride $(\mathrm{Cl})$ & 0.0545 & 0.005445 & 0.0490 \\
\hline Sulphate $\left(\mathrm{SO}_{4}\right)$ & 0.8833 & 0.088333 & 0.7950 \\
\hline Phosphate $\left(\mathrm{PO}_{4}\right)$ & 0.0204 & 0.0020449 & 0.1884 \\
\hline Potassium $(\mathrm{K})$ & 0.1089 & 0.01089 & 0.0980 \\
\hline Copper $\left(\mathrm{CU}^{2+}\right)$ & 0.1159 & 0.0115918 & 0.1043 \\
\hline Bio-coagulant & 10.3435 & 6.2061054 & 4.1374 \\
\hline & 12211.8166 & 1226.353412 & 10985.4632 \\
\hline
\end{tabular}

Table 6 - Material Balance for the Filtration Unit

\begin{tabular}{|l|c|c|c|}
\hline \multicolumn{1}{|c|}{ Component $(\mathrm{g})$} & $\mathrm{In}(\mathrm{S} 5)$ & Out filter(S6) & Out(S7) \\
\hline Water & 10980.0000 & 549.0000 & 10431.00000 \\
\hline Nitrate $\left(\mathrm{NO}_{3}\right)$ & 0.1693 & 0.0000 & 0.1692 \\
\hline Iron $(\mathrm{Fe})$ & 0.0904 & 0.0000 & 0.0904 \\
\hline Fluoride $(\mathrm{F}-)$ & 0.0014 & 0.00000 & 0.0014 \\
\hline Chloride $(\mathrm{Cl})$ & 0.0490 & 0.0000 & 0.0490 \\
\hline Sulphate $\left(\mathrm{SO}_{4}\right)$ & 0.7950 & 0.0000 & 0.7950 \\
\hline Phosphate $\left(\mathrm{PO}_{4}\right)$ & 0.1884 & 0.00000 & 0.0184 \\
\hline Potassium $(\mathrm{K})$ & 0.0980 & 0.0000 & 0.0980 \\
\hline Copper $\left(\mathrm{CU}^{2+}\right)$ & 0.1043 & 0.0000 & 0.1043 \\
\hline Bio-coagulant & 4.1374 & 4.0133 & 0.1241 \\
\hline & 10985.4632 & 553.0133 & 10432.4499 \\
\hline
\end{tabular}


From Table 4, In(S1) stands for the total components in the first input stream, In(S2) stands for the full details in the second input stream and Out(S3) stands for the total components in the first output stream.

Also, it was observed that the sum of $\operatorname{In}(\mathrm{S} 1)$ and $\operatorname{In}(\mathrm{S} 2)$ less Out(S3) equals 3.2E-07 which is almost zero indicating steady-state condition. From Table $4 \operatorname{In}(\mathrm{S} 3)$ is the total components in the first input stream and sludge(S4) and Out(S5) are the two output streams full features, it was observed that In(S3) less the sum of sludge(S4) and Out(S5) gives zero which have revealed steadiness in the operation of the treatment process.

From Table 6 In(S5) is the total components in the first input stream while out the filter (S6) and
Out(S7) are the two output streams full details, respectively. In(S5) less the sum of Outfitter (S6) and Out(S7) equals zero, which also showed steadiness in the operation of the treatment process.

However, the performance results of a prepared extract of Balanites aegyptiaca seed powder and the processed powdered coagulant on the turbid water after treatment showed decreased $\mathrm{pH}$, colour, and total coliform count other inorganic constituents. Also, pH drops from 7.1 to 6.91, turbidity from 514 NTU to 26.5 NTU, colour from 5600.00 PCU to 290.00 PCU and total coliform count from $85 \mathrm{CFU} / 100 \mathrm{ml}$ to $10 \mathrm{CFU} / 100 \mathrm{ml}$.

Other constituents present significantly decreases after treatment; detail on the result is as shown in Table 7.

Table 7 - Results of Turbid Water before Treatment and Performance Results of Stock Solution of Balanites Aegyptiaca Seed and Powdered coagulant on the Turbid Water after Treatment

\begin{tabular}{|c|c|c|c|c|c|}
\hline Parameters / Units & $\begin{array}{l}\text { Coagulant } \\
\text { extract }\end{array}$ & $\begin{array}{l}\text { Powdered } \\
\text { Coagulant }\end{array}$ & $\begin{array}{c}0 \text { - dosage Turbid } \\
\text { Water before }\end{array}$ & Treatment & NIS/WHO \\
\hline Temperature ${ }^{\circ} \mathrm{C}$ & 27.400 & 27.30 & 27.200 & 27.900 & Ambient \\
\hline $\mathrm{pH}$ & 6.91 & 7.22 & 7.17 & 7.100 & $6.5-8.5$ \\
\hline Conductivity $(\mu \mathrm{s} / \mathrm{cm})$ & 441.00 & 474.00 & 424.00 & 276.00 & 1000.00 \\
\hline Total dissolve solid (mg/l) & 220.00 & 237.00 & 212.00 & 139.00 & 500.00 \\
\hline Turbidity (NTU) & 26.500 & 90.74 & 234.68 & 514.00 & 5.00 \\
\hline Colour (PCU) & 290.00 & 900.00 & 2300.00 & 5600.00 & 15.00 \\
\hline Total suspended solid (mg/l) & 20.00 & 47.00 & 130.00 & 115.00 & - \\
\hline Nitrate $\left(\mathrm{NO}_{3}\right)(\mathrm{mg} / \mathrm{L})$ & 3.49 & 4.81 & 11.18 & 19.03 & - \\
\hline $\operatorname{Iron}(\mathrm{Fe})(\mathrm{mg} / \mathrm{L})$ & 0.300 & 2.300 & 5.70 & 8.60 & 0.30 \\
\hline Fluoride(F-) (mg/L) & 0.13 & 0.00 & 0.00 & 0.00 & 1.50 \\
\hline Chloride (Cl-) (mg/L) & 1.00 & 1.60 & 2.30 & 5.50 & 250.00 \\
\hline Sulphate $\left(\mathrm{SO}_{4}\right)(\mathrm{mg} / \mathrm{L})$ & 0.00 & 0.00 & 52.00 & 73.00 & 100.00 \\
\hline Phosphate $\left(\mathrm{PO}_{4}\right)(\mathrm{mg} / \mathrm{L})$ & 0.31 & 0.95 & 1.80 & 2.00 & - \\
\hline Potassium(K) (mg/L) & 23.00 & 9.50 & 29.00 & 32.00 & - \\
\hline Copper $\left(\mathrm{Cu}^{2+}\right)(\mathrm{mg} / \mathrm{L})$ & 0.42 & 1.30 & 2.65 & 10.00 & 1.00 \\
\hline Total-alkalinity (mg/L) & 155.00 & 240.00 & 400.00 & 950.00 & - \\
\hline Total Coliform Bacteria (cfu/100mL) & 10.00 & 10.00 & 55.00 & 85.00 & 10.00 \\
\hline
\end{tabular}

When such an outcome is compared with the turbid water's impact before treatment as presented in Table 7, the product agrees with similar work conducted as reported by [14]. Furthermore, when the powdered coagulant was used for the treatment on the developed treatment units, there was also improvement in the treatment process as a decrease in potassium content was observed compared with the result obtained when a stock solution of Balanites aegyptiaca Seed Powder was used as bio-coagulant. This is presented in Table 7. After treatment, the turbid water's microbiological property showed that Balanites Aegyptiaca seed powder and extract have good disinfecting stuff in water treatment than the set standard of $10 \mathrm{CFU} / 100 \mathrm{~mL}$ as set by [15]. When subjected to treatment, this study's turbid water also showed a remarkable reduction in its constituents, as presented in Table 7.

The findings are in agreement with the literature, as reported by [13]. It was also observed that coagulation-flocculation occurs within a specific $\mathrm{pH}$ range; different $\mathrm{pH}$ provides different colour [17]. 
Detail of the result is as presented in Table 7. Also, Balanites aegyptiaca seed and extract solution used as coagulant and disinfectant in comparison with the synthetic coagulants and disinfectants have a more comparative advantage over the synthetic ones used in water purification as showed in the results obtained in Table 6, the statement above complies with the literature $[1,5]$.

\section{CONCLUSION}

This paper reported developing a bench-scale water treatment unit for the treatment of medium turbid water. The total tank design capacity was 20.00 Liters with the overflow area's actual size for sedimentation of 7.46 Liters. The result of the treatment process using the stock solution and the powdered bio-coagulant on developed water treatment unit revealed remarkable reduction in the tested parameters in the raw turbid water used for the treatment process including total coliform count which reduces from $85 \mathrm{CFU} / 100$ $\mathrm{mL}$ to $10 \mathrm{CFU} / \mathrm{mL}$ in both cases. It was observed that conductivity increases after the treatment, but other inorganic constituents reduce significantly though not to WHO and NIS's recommended set standard. The bio-coagulant application can be a sustainable and more cost-friendly alternative to non-bio-coagulant to purify medium to highly turbid water. However, the optimisation of the entire treatment process in this study is required to achieve optimum performance.

\section{ACKNOWLEDGEMENT}

We duly recognise the hard work of those who contributed to their time and wealth of knowledge particularly Abubakar Tafawa Balewa University Bauchi-Nigeria Faculty of Engineering Lecturers for their resilient attitude and concern, constructive criticism and encouragement towards this research.

\section{REFERENCES}

1. A. Muyibi, S., \& Fakrul Razi Ahmadun, S. A. A. M. J. M. M. N. (1970). Enhanced Coagulation Efficiency of Moringa Oleifera Seeds Through Selective Oil Extraction. IIUM Engineering Journal, 4(1). doi: 10.31436/iiumej.v4i1.366

2. Azene, T. (2015). Balanites (Balanite aegyptiaca) Del., Multipurpose Tree a Prospective Review. International Journal of Modern Chemistry and Applied Science , 2(3), 189-194.

3. Clark, M. R., \& Silvaganesan, M. (1998). Predicting chlorine residuals and formation of TTHMs. Journal of Enviromental Engineering, 124(12), 1203-1210.

4. Dayal, L. C., \& Vaghasiya., H. U. (2011). A review on Balanites aegyptiaca Del (desert date): phytochemical constituents, traditional uses, and pharmacological activity. Pharmacognosy Review, 5(6), 55-66.

5. de Souza Fermino, L., de Castro Silva Pedrangelo, A., de Matos Silva, P, de Azevedo, R., Yamaguchi, N., \& Ribeiro, R. (2017). Water Treatment with Conventional and Alternative Coagulants. Chemical Engineering Transaction, 57, 1189-1194.

6. Desh-pande, L. (2010). Water quality analysis. laboratory Methods. Retrieved from https://www.mpcb.gov.in/sites/default/files/water-quality/reports/LSD-NEERI\%20Water\%20Quality\%20Analysis.pdf

7. Doerr, B. (2006). Moringa for Emergency Water Treatment. Retrieved from https://www.echocommunity.org/resources/7ef0bc2c-2356-4eb9-91ba-6af07e251619

8. Elfeel, A. A. (2010). Variability in Balanite aegyptica var. aegyptica seed kernel oil , protein and minerals contents between and within locations. Agricultural and Biological Journal of North America, 1(2), 170-174.

9. Hall, J. B., \& Walker, D.H. (1991). Balanites aegyptiaca Del. In School of Agricultural and Forest Science (pp. 1-12). Banger: University of Wales.

10. Hendrawati, Eti, R., Hefni, E., \& Latifah, K. D. (2015). Characterisation of physicochemical properties of nano-sized moringa olifera seed powder and its application as natural coagulant in water purification process. Journal enviromental and earth science, 5(25), 19-26. 
11. Islam, M. N., Sabur, A., Ahmmed, R., \& Hoque, M. E. (2015). Oil Extraction from Pine Seed (Polyalthia longifolia) by Solvent Extraction Method and its Property Analysis. Procedia Engineering, 105, 613-618. doi: 10.1016/j.proeng.2015.05.039

12. Kumar, V., Othman, N., \& Asharuddin, S. (2017). Applications of Natural Coagulants to Treat Wastewater - A Review. MATEC Web of Conferences, 103, 06016. doi: 10.1051/matecconf/201710306016

13. Muhammad, I. M., Abdulsalam, S., Abdulkarim, A., \& Bello, A. A., (2015). Water Melon Seed as Potential Coagulant for Water treatment. Global Journal of research in Engineering: Chemical Engineering, 15(1), 1-9.

14. Muhammed, F. B., Muhammad, I. M., Gutti, B., Abdulkarim, A. Y., \& Ahmed, S. I. (2018). Characterisation and Application of Balanites Aegyptiaca Seed (Desert Date) Kernel as a Natural Coagulant and Disinfectant for water purification. Nigerian Journal of Engineering Faculty of Engineering Ahmadu Bello University Samaru- Zaria, Nigeria, 24(2).

15. N. d. (2007). Nigerian Standard for Drinking Water Quality (NIS 554:2007). Retrieved from https://www.health.gov.ng/doc/StandardWaterQuality.pdf

16. Phani, M. T., \& Rajkumar, R. (2013). Utilisation of natural coagulant for reduction of turbibdity from waste water. International Journal of Chen Tech Research, 37(4), 1119-1123.

17. Seyrig, G. and Shan, W. (2007) Coagulation and flocculation: color removal, Unpublished PhD thesis, College of Engineering, Michigan State University, Michigan.

18. Sulaiman, Y., Saidat, O. G., Maryam, I., \& Abdulwahab, G. (2016). Extraction of Oil from Jatropha Seed Kernel: Optimisation and Characterisation. International Journal of Chem Tech Research, 9(5), 758-770.

19. Vijayaraghavan, G., Sivakumar, T., \& Vimal Kumar, A., (2011) . Application of Plant Based Coagulant for Waste Water Treatment. International Journal Advance Engineering Research and Studies, 1(1), 1-5.

20. Vinitha, J. J., Abubakar, Y., Mohammed, I. K., Mohammed, R., \& Mohammed, S. T. (2014). Extraction of natural coagulant from Royal poinciana (Delonix regia) seeds to treat turbid water. International Journal of emeerging technology and advanced engineering, 4(4), 940-972.

21. Wikipedia (2018). Balanite Aegyptiaca. Retrieved from https://en.wikipedia.org/wiki/Balanites_aegyptiaca

22. Zaharaddeen, N. G., Casimir, E. G. \& Paul, E. (2013). Production and characterisation of biobased transformer oil from Jatrophacurcasseed. Journal of Physical Science, 24(2), 49-61. 